\title{
Measuring Customer Based Place Brand Equity (CBPBE) From A Public Diplomacy Perspective: Evidence From West Bengal
}

\begin{abstract}
A glaring paucity of a measuring instrument for place branding effectiveness and place brand equity still remains. This study contributes theoretically by exploring and developing the dimensions and instrument of customer based place brand equity (CBPBE) quantitatively, in the context of international relations (public diplomacy) between two places, West Bengal (in India) and Bangladesh. To this end, the study employed: focus group discussion, depth interviews and survey, in order to develop and validate the items generated to measure CBPBE. Confirmatory factor analysis was used on a total sample of 437 respondents that resulted in a nine (9) item CBPBE scale, represented by multidimensional constructs namely: place brand salience, perceived quality and place brand engagement. The CBPBE construct is then tested with brand loyalty - investment attractiveness construct in a conceptual model in order to verify the nomological relationship of the instruments developed.
\end{abstract}

Keywords - Place branding, place brand equity, customer based place brand equity (CBPBE), customer based brand equity (CBBE), public diplomacy. 


\section{Introduction}

Place branding and public diplomacy are two important concepts that enhance a country or a place's brand image. While place branding is considered as the marketing, branding and the commercial aspect of a place or a country, with the aim to increase sales and profit of the place or a country (Anholt, 2010), public diplomacy traditionally relates to a country's foreign policy through its public relation (PR) communication, with the intention to influence both international and domestic audiences' (or public) perception to create a favorable opinion and image towards the country. Although the two concepts differ in the way they are communicated and promoted, both concepts have similarities, as they both promote the place or the country's brand image (Gilboa, 2008) through citizen engagement. Szondi (2008) in this regard observes that in countries like UK and Canada branding strategies are used for better communication and engagement with citizens.

The efficacy of public diplomacy lies in influencing views, decisions and behavior of the place's stakeholders including friends, enemies and own people. Therefore, it is now a known fact that states and governments are venturing into public diplomacy with a motive to influence its targeted audience (both international and domestic) and targeted stakeholders. Similar to a marketer's desire to generate specific set of behavior(s) from its existing and targeted buyer, one way of achieving this is via branding the product or service. In the context of a place, Ham (2001) points to this very phenomenon of public diplomacy as a branding tool.

It is a testimony to the fact that place branding and public diplomacy are essentially intertwined that the first dedicated journal on place branding is titled 'Place Branding and Public Diplomacy. In its second issue the editor observed (Anholt, 2005 p. 119) "that ministries of foreign affairs and their foreign services must practice something called 'public diplomacy'; likewise the fact that public affairs has become an international affair, and that investment promotion and tourist promotion must be as sophisticated as the most sophisticated commercial 
marketing, since both are competing for consumer mindshare in the same space." He went on to state that in a golbalised marketplace, places compete with one another for share of reputation, goodwill and trust (the very essence of public diplomacy). Therefore, it is most logical that places look into domains of marketing to understand how to prosper in a competitive world.

However, despite the relatedness of the two concepts, they have been studied separately in the past. This is due to the fact that most previous studies in public diplomacy were historical and mostly dealt with anecdotal or personal opinions, which lacked conceptual or theoretical background in nature, resulting in the lack of contribution to the development of theory and methodology (Gertner, 2011). More importantly, these studies were not related to branding and marketing, but rather to topics on urban planning, geography and other social science, hampering the understanding of the potential effect of place branding on public diplomacy (Anholt, 2010; Gertner, 2011). Limited empirical evidence exist on their connection (Anholt, 2010); how these are connected and how they both enhance a place brand's image are still unclear (Gilboa, 2008; Anholt, 2010). Assuming Anholt's (2005) opinion that public diplomacy is a perspective to place branding is true, then the most obvious question is how to measure public diplomacy efforts in the context of place branding and its impact thereof. Therefore, the overarching question as to whether public diplomacy can contribute to objectively and/or quantifiably measure the efficacies of place marketing and place branding thereof remains primarily unanswered.

To fill the above gaps and to illustrate the importance of combining the two concepts, this study tries to answer the question of how a place's brand equity can be achieved among target citizens or customers via the use of public diplomacy. We note that empirical research concerning these two concepts and its effect on overall brand equity and its measurement are still unclear. Hence, there still remains a glaring paucity of a measurement instrument for place branding effectiveness and place brand equity thereof. With exception, Anholt (2007) developed index for nation and city branding that is presently being cooperated by the research firm GfK 
(www.gfk.com), which was useful and provide the starting point in this area, but the validity of the specific measures used remain a question and would require extensive research before replication (Gilboa, 2008). Similar, indices are being used by consultancy firms like Saffron Brand Consultants (Hildreth, 2008), FutureBrand (www.futurebrand.com) and Bloom Consulting (www.bloom-consulting.com). However, most of these indices are restricted to either geographical focus or sectoral focus. While Anholt - GfK, FutureBrand and Saffron Brand consultants' indices focus either only on selected cities or nations, Bloom Consulting index focuses on performance related to either trade or tourism. Academic research on modelling and valuation of place brands were taken up by Paliaga, Franjic and Stuenje (2010) and Sevin (2014). However, the methodology used by Paliaga et al. (2010) was more based on accounting equations on historical data rather than customer attitudes. Therefore, such research though capable of financially measuring brand value is not suitable for making strategic branding decisions.

We acknowledge that brand equity for place has been studied (Zenker \& Martin, 2011; Zenker, 2014); these studies however approach their brand equity measures from a single perspective, i.e. marketing and branding only, thus only product or economic perspectives are explained (Bose, Roy \& Tiwari, 2016), ignoring the effect of both of these concepts (public diplomacy and place brand), which can also potentially deal with dispute cases and strengthen the brand image of the place (Ham, 2001; 2002). On the other hand traditional measures of public diplomacy primarily suffer from issues of lack of quantitative measurement (Matwiczak, 2010) and restricting its focus primarily on international audience (Pamment, 2014; Sevin, 2015). In such cases domestic public diplomacy and subnational players' public diplomacy get marginal importance.

For the purpose, of answering this aforesaid question the study ventures into developing a psychometrically robust instrument that can measure place brand equity among target audience given the place's public diplomacy strategies and initiative. We aim to bridge these two concepts 
and explain how these work from the marketing perspective in potentially enhancing various positive outcomes between entities (the focused place and its target audience). It serves the purpose of reiterating the place's (brand's) promise to its target audience (customers) including solving tensions between two regional entities in the case of dispute and/or fostering brotherhood and cooperation (as in case of West Bengal and Bangladesh) (Bose et al., 2016).

West Bengal (a state in eastern India bordering Bangladesh) and Bangladesh as has been considered as the place brand and contextualizes the study for the following reason. The water dispute between the state of West Bengal (India) and Bangladesh illustrates the link between place branding and public diplomacy well. This is because the dispute has resulted in tension between the two nations, and attempts were made to resolve this issue through public diplomacy that led to the formation of the 'Teesta river water sharing treaty'. Consequently, the brand image of India enhanced among the citizens of Bangladesh, who are major customers of medical tourism in India. In addition, Bangladesh is considered as a key economic partner and strategic ally against terrorism and trafficking (Dash, 2016). However, the diplomatic standstill that took place between India and Bangladesh relating to the Teesta river water sharing treaty led to the subsequent denigration of West Bengal's image as well as image of India among Bangladesh nationals (Ahmed, 2012).

In addition to conceptually advancing the development and validation of the CBPBE scale, the study has important implications for public diplomacy practitioners and place branding experts. The research makes significant conceptual and empirical contributions to the domains of place branding and place brand equity.

The rest of the paper is organized as follows: first, the constructs are defined and relevant literature is reviewed. Next, scale development and validation processes are discussed followed by the data collection and analysis section. Finally, the implications of the research are discussed along with the limitations and future research directions. 


\section{Construct Definitions and Literature Review}

\subsection{Constituents of Place Branding}

Researchers consider country of origin (COO) (Papadoplous \& Heslop, 1993, 2002), place and/ or destination brands (Kotler \& Gertner, 2002), national identity (Smith, 1991; Bond, McCrone \& Brown, 2001) and public diplomacy (Ham, 2001; Fan, 2010) as the underpinnings to examine place branding. Bose (2014) has corroborated this finding and mentions these four perspectives of place branding as independent though they might be interrelated. These four perspectives of place branding are destination branding, public diplomacy, regional identity, and investment attractiveness (Bose et al., 2016).

\subsection{Public Diplomacy (PD)}

There is an ongoing debate among the scholars and practitioners regarding a universal definition of public diplomacy. For example, Malone (1985, p. 199) defines public diplomacy as "direct communication with foreign people, with the aim of affecting their thinking, and ultimately, that of their own governments." Subsequently, Tuch (1990) and Frederick (1993) add the communication source or controller of the communication and the information type respectively. Signitzer and Coombs (1992) consider that public relations and public diplomacy are very similar because of their similar objectives and use of similar tools. These authors define public diplomacy as "the way in which both government and private individuals and groups influence directly or indirectly those public attitudes and opinions which bear directly on another government's foreign policy decisions" (p.138). This approach to public diplomacy is crucial for the evolution of the construct as it removes the myopic idea that public diplomacy is only made by governments. 
Experts suggest that public diplomacy is about yielding 'soft power' (international relations) through communication (Melissen, 2005). They operationalize public diplomacy as official policy that translates soft power resources into actions. The second perspective to public diplomacy is the relation between the media and government to frame public opinion. Scholars, in the domain of foreign affairs, identify nation branding gaining prominence which acts as connect between the two distinct domain of branding (marketing) and public diplomacy (Dinnie, 2005; Olins, 2005). The concept of a 'brand state' (Ham, 2001) refers to the international audiences' thoughts and feelings about the state.

There is an evolving school of thought that considers the role of domestic audience in public diplomacy (Tyler et al., 2012; Just, 2015). Tyler et al., (2012) report that in the case of Australia in 2007 the Senate Standing Committee for Foreign Affairs, Defence and Trade recommended public communication strategy and designing of programs to inform the Australian public about the public diplomacy of Australia. Just (2015) examined the domestic public diplomacy efforts of Poland to develop opinions among its nationals which in turn have helped the nation achieve international credibility.

This study consider public diplomacy that includes domestic public diplomacy to be all the activities undertaken by regional and national authorities based on the context of the place to form positive opinion about the place and is inclusive of international relations, public relations and any other process that influences public opinions and attitudes towards the particular place.

\subsection{Customer Based Place Brand Equity (CBPBE) and Customer Based Brand Equity(CBBE)}

The extant literature on brand equity has been primarily in favor of destination branding or

place as a tourism destination (Gartner \& Ruzzier, 2010; Im et al., 2014; Kadou \& Kehagias, 2014) or from destination marketing organization perspective (Pike, 2007; 2009). Other related 
research are primarily focused on brand association and/or brand image (Donner, Fort \& Vellema, 2014; Shafranskaya \& Potapov, 2014) and are primarily qualitative in approach. These researches did not provide quantifiable measure of place brand equity.

For the purpose of developing the measurement instrument, the researchers put forward the working definition of CBPBE as the customer based brand equity of a 'place'. The customer based brand equity is conceptualized in the lines of the definitions and descriptions of CBBE proposed by Aaker (1996b) and Keller (1993). In this context, customers are both domestic and international audiences whose opinions and images about a particular place get formed due to the public diplomacy efforts undertaken by that place's administration. The contextualization of 'customer' in this study is based on the fact that the audience that public diplomacy addresses is analogous to the marketing interpretation of the term. The term 'customer' can take the form of varying stakeholders (Garcia, Gomez \& Molina, 2012; Merrliees, Miller \& Herington , 2012) to the place that the public diplomacy focuses on. This can be substantiated with Anholt's (2005, p. 118-119) claims that “....cities and regions can be promoted, they certainly do have brands, and those brands certainly do affect the views, decisions and behavior of their friends, enemies, allies, visitors, investors and consumers."

Aaker (1996b) defines customer based brand equity (CBBE) as a set of all assets and liabilities that a brand (name and/or symbol) can be attached with. These assets and liabilities in turn would provide the customer consuming the product or service with additional value. This 'value added' provided by the product or service results in price premium and/or customer loyalty towards the brand (Aaker, 1996b; Keller, 1993; Pitta \& Katsanis, 1995). CBBE as conceptualized by Aaker (1996a, 1996b) has five components: (a) brand awareness; (b) brand; (c) perceived quality; (d) brand loyalty; and (e) other proprietary assets such as copyrights, patents and trademarks. Keller's (1993) approach to CBBE is similar to that of Aaker (1996a, 1996b) 
and posits that the differential effect in response to the customer (brand loyalty) towards the particular product/service is due to the brand.

It must be kept in mind that proprietary brand assets like trade mark or copyright need not be present for all brands. Most of the brand equity measurement scales that approach CBBE from Aaker (1996b) perspective measure brand equity on the basis of brand awareness, brand association (image), perceived quality and brand loyalty (Yoo \& Donthu, 2001; Netemeyer et al., 2004). Therefore, proprietary brand assets are not generally considered as a measure of brand equity when considering place brand equity (Gartner \& Ruzzier, 2010; Bose et al., 2016).

\subsection{Linking Place Branding with Public Diplomacy}

Place branding is defined as " a network of associations in the consumers' mind based on the visual, verbal, and behavioral expression of a place, which is embodied through the aims, communication, values, and the general culture of the place's stakeholders and the overall place design” (Zanker \& Braun, 2010, p.4). Within the context of brand equity for a place, previous studies have predominantly been applied in the context of destination branding that deals with tourism marketing and tourism destination image (TDI) (Pike, 2007, 2009; Elliot, Popadopoulos \& Kim, 2010; Gartner \& Ruzzier, 2010) and from the aspect of country of origin (COO) effects and product country image (PCI) (Pappu, Quester \& Cooksey, 2007; Fetscherin \& Toncar, 2010; Prendergast, Tsang \& Chan, 2010). In addition to these traditional perspectives on place branding, scholars argue that place branding can also be studied from the regional identity perspective (Singleton \& McKenzie, 2008; Williams et al., 1995) and public diplomacy (Jones \& Smith, 2006; Basu, 2007). Public diplomacy is defined as, “a government's process of communication with foreign publics in an attempt to bring about understanding for its nation's ideas and ideals, its institutions and culture, as well as its national goals and policies" (Tuch, 1990, p. 3). 
Implementing public diplomacy using marketing and brand orientation will result in an increase in 'competitive identity' (Anholt, 2010, p.94) and increased brand equity of the place (Ham, 2002). With increased brand equity, a place can enjoy more tourists (domestic and international), attractive investments (FDIs and domestic), and students and expand exports (Cardinale et al., 2016; Hafeez et al., 2016) and reach higher standards of living (Ham, 2002). Public diplomacy is thus a key driver for place branding and has a direct relationship with investments, exports and tourism (Bose et al., 2016). Rainisto (2003) mentions place branding and marketing as the process of creating place identity. Place branding thus, involves, creation of identity and reinforcement of the identity through associations (image) and subsequent customer behavior based on the values that the place offers. In the branding context, these are referred to as the domain of customer based brand equity (CBBE) (Aaker, 1996a; Keller, 1993). This finds support in Ruzzier and Chernatony (2013) who argue that growth of place brands is dependent and impacted by strategic focus towards brand identity and brand equity. While developing brand profiles for stressed satellite cities, Merrilees, Miller, and Herrington (2013) use the same paradigms and operationalize their model based on brand image which acts as a consequence of identity and antecedent for equity. This is how place branding is connected to public diplomacy (Gilboa, 2008; Anholt, 2010).

Hence, by implementing a brand orientation to a place through public diplomacy campaign for example, could increase competitive identity (Anholt, 2010) and enhancing a nation or a place's brand equity (Ham, 2002). Likewise, Ham (2002, p. 252) emphasise the importance of applying brand orientation in public diplomacy because of the "shift in political paradigms from the modern world of geopolitics and power to the postmodern world of images and influence.", Therefore, place/states that fail to "establish 'relevant brand equity" will not be able to successfully compete economically and politically in the new world system" (Gilboa, 2008, 67). Thus, without an adequate understanding of place brand equity and public diplomacy, it 
hampers our understanding in terms of how we can deal with our competitors better and enhance our ability to be seen as 'competitive identity' (Anholt, 2010).

Although traditional thinking considers public diplomacy to be contextually national in nature, tensions among different nations suggest that regional issues and sub-national actors impact public diplomacy and thus place branding to a great extent (Wang, 2006). This finds support in the perspectives of regional authorities like the state government of Gujarat engaging in public diplomacy hosts the 'Vibrant Gujarat' summit (www.vibrantgujarat.com) for national and international industrialists and investors to promote the state as an attractive investment destination or for that matter the role of West Bengal in maintaining relationships with Bangladesh and Bhutan (Tewari \& Pant, 2016). In their work on paradiplomacy, Tewari and Pant (2016) mention that, “West Bengal can have more successful paradiplomatic relations with Bangladesh and Bhutan than an MEA official stationed at the country's capital. Similarly, Kerala has vested interests in engaging in diplomatic relations with the Gulf nations as a large number of the state's residents find jobs there." Hence, combining the place branding and public diplomacy concepts have widespread theoretical and practical relevance.

\section{Development of Scale to Measure Customer Based Place Brand Equity (CBPBE)}

\subsection{West Bengal as the Place Brand}

West Bengal which lies along the borders between India and Bangladesh is chosen as the 'place' for the research as it is a shining example of historical relationship and friendship between India and Bangladesh on the one hand and diplomacy crisis on the other.. The state (region)was in the middle of a public diplomacy crisis between India and Bangladesh due to the Teesta river water sharing agreement (as mentioned earlier). The result of non-signing of the mentioned agreement between the two countries due to open disinterest by the West 
Bengal government led to a negative image of the state among the political class as well as the masses in Bangladesh (Dayal, 2012; Leight, 2013).

West Bengal as a place brand from the public diplomacy's perspective, receives the most number of inbound tourists from Bangladesh in entire India (www.dailyworld.in), and a high percentage of post graduate and undergraduate students compared to all other Indian states (www.aishe.nic.in). It has the greatest number of legal and illegal immigrants post 1971 (Shamshad, 2017), thus making its appropriate choice for this study. The final issue also relates to a diplomatic row between India and Bangladesh pertaining to illegal migration from Bangladesh to West Bengal (Bhardwaj, 2011; Dutta, 2004) and has affected the image of West Bengal in Bangladesh.

In addition to the above reasons, the choice of West Bengal as a place brand can also be seen through a geographical lens. The choice may be justified in the context of the tourism potential it holds as a destination brand, the branding opportunities the state possesses given its regional identity, leveraging the power of 'Darjeeling' tea's international GI (geographical indication) or the potential to attract investments. However, the present study is restricted to only public diplomacy (Bose, 2014; Bose et al., 2016).

\subsection{Item generation}

In order to generate items for customer based place brand equity (CBPBE), three methods were adopted namely: (1) public diplomacy and place branding literatures were extensively consulted; (2) focus group discussions (FGDs) were conducted to help generate items for place brand equity and (3) depth interviews (DIs) among representatives from the ruling party and the opposition in West Bengal were conducted.

Review of literature is borne out of the 'deductive' approach to scale development. The approach stands on the premise that theoretical foundation provides enough information for 
generating the initial set of items. Review of literature thus enables development of the theoretical definition of the construct. Items can then be generated from this definition (Hinkin, 1998).

The 'inductive' approach is appropriate when theoretical and/or conceptual basis of the construct is incapable of generating easily identifiable dimensions for which measurement items can be developed. Respondents are asked to subjectively describe a phenomenon. That is, the respondents were asked to describe the phenomenon that is related to public diplomacy, which was explained to the respondents based on the PR and media promotion activities taken up by the state to generate positive vibes/ideas/images about the state and negate the existing ones. Subsequently, the responses are categorized. From these categorized responses, the items are generated (Hinkin, 1998). FGDs and DIs are among the popular techniques of inductive item generation process. The paucity of distinct quantifiable measure in the public diplomacy literature was the major reason for conducting FGDs and DIs in this study.

Public diplomacy does not have any established instrument that quantitatively measures its effectiveness. Therefore, literature related to measurement of public diplomacy efforts (Pahlavi, 2007; Matwiczak, 2010; Banks, 2011) is reviewed and initial measurement attributes are developed based on these approaches (see Table 1).

Insert Table 1 here.

Two structured focus group discussions (FGDs) with eight respondents each lasting for about thirty minutes were conducted. The first FGD comprised of public officials and media executives belonging to different parts of India but presently residing in the state of West Bengal, India between the age of 45 years and 67 years. This group was the representation of the two focused domains of our study. The sub-group of public officials gave us the 
administrative perspective of West Bengal as the 'brand' and its public diplomacy approaches thereof. The sub-group of media executives provided their perspectives on brand communication and brand building considering West Bengal as the brand. The second FGD represented young executives (age 28-33 years) from different industrial sectors like media, reality, IT, banking and research and consultancy. The reason for selecting such diverse group of respondents was to seek different perspectives to a common issue. Fern (1983) advocate for group heterogeneity to get differences in perspectives. This research follows both the methods by conducting FGDs with different respondent groups (homogeneous and heterogeneous) as proposed by Askegaard and Kjeldgaard (2007) in their study on place branding through food. The respondents were asked to provide reasons for a place to have positive images among target audiences. These authors also elucidated why they would consider a particular place to be good with respect to their particular interests in that place. Further, the respondents were asked to deliberate in details about the effect of government machinery in promoting the place and how various media impacts the perceptions about the place. Subsequently, the respondents were asked to consider West Bengal from the public diplomacy perspective. The respondents were asked to give their opinion about issues that they consider important when considering West Bengal as a place brand.

The thematic analysis of place brand equity of West Bengal given its public diplomacy is shown in Table 2.

Insert Table 2 here.

In addition to the FGDs, the study also undertook four depth interviews (DIs), since public diplomacy is a specialized domain where experts and concerned authorities are better equipped 
to comment on the matter. The respondents represented senior government official, two members of the ruling party and one member of the opposition. The respondents' respective ages were between 43 years and 71 years. We used the DI protocol of 'General Interview' using follow up questions as deemed necessary (Turner, 2010). Interviews were conducted with senior members of the ruling party and the opposition, respectively.

During DI, the respondents were asked about the ways and means of doing diplomacy considering both foreign audience as well as domestic audience. In addition, they were asked to explain how they gather positive public opinion about their actions and subsequently the state as a whole. They were asked about the public diplomacy issues relating to Teesta water sharing agreement and their perspectives on this issue. The three political representatives (from the ruling party and the opposition) were also asked to provide their opinions about the present public diplomacy scenario of the state. Lastly, they are asked about the options in hand of the concerned administration regarding public diplomacy efforts to enhance the brand 'West Bengal' (see Table 3).

Insert Table 3 here.

From the DIs three interesting perspectives to public diplomacy and subsequent place brand equity emerged. Firstly, the public diplomacy efforts are the reflection of the government's desire to portray the set of images it wants for itself and the region. An expert opine:

"To understand the image of a place or a region one must understand its recent history and all the actions that were taken by earlier governments. It is imperative that with actions and policies of governments the images of the region would be developed. Thus, it is not static and absolute rather dynamic and tends to be affected by more contemporary 
events and governments. If a government is shambolic the image would always be negative irrespective of the public diplomacy efforts that the government might put in."

Secondly, circumstances might create a situation where the actions of a regional authority supersedes the actions of the national authority thus affecting the region's brand equity more than the nation itself in the minds of the other party. As expressed by a representative of the government:

"The Prime Ministers were interested in signing the agreement and there was huge interest in this agreement within Bangladesh. Therefore, the West Bengal Chief Minister became the villain in the eyes of Bangladeshis as the Indian Prime Minister had to back out from this agreement at the last moment owing to the Chief Minister's protests. The river is slowly drying up and in winter the volume of water is hardly enough for just north Bengal let alone being shared with Bangladesh. Therefore, even after repeated efforts from West Bengal to explain to the Bangladesh representatives that let river experts first evaluate the situation and then the agreement will be signed, people of Bangladesh think that we are saboteurs and the only cause behind this failure."

Third, public diplomacy is targeted at wider audiences. The inherent logic is to make some of these audiences believe in the sincerity and integrity of the state/ regional authority. These set of believers/ loyalists in turn enable the state to convert such audiences towards itself as they directly/ indirectly influence others who have stakes in that region. A representative of the ruling party observed that:

"Efforts must be made to reach out wider groups that have a stake in what we do or want to do. For the locals of West Bengal we must act as sincere nurturing mother. This sincerity and seriousness if properly communicated to our people they would make them trust us and 
act as our messengers to the disenfranchised. Similarly, for Bangladesh irrespective of whatever crisis that has taken place we spare no efforts to send across the message that we are their caring and concerned neighbours. The Bangladeshis who believe in us spread across this message to their close ones about the sincerity, hospitability and good intentions of us towards them. Perhaps, the most important aspect of this effort is to make the investors and business community believe us. They are a closed knit group so convincing even a few of them helps us a great way in promoting ourselves to the entire fraternity."

The qualitative findings (Tables $2 \& 3$ ) along with the literature review on CBPBE an inventory of 11 items were generated that make a place a strong brand due to the public diplomacy efforts (refer to Table1). For content and face validity purposes, two academics from marketing and operations and one faculty from international relations department reviewed these items. Based on their suggestions two items were deleted as those were deemed to be confusing and redundant. Therefore, the screening resulted in a pool of 9 items. Subsequently, these nine items were used in a questionnaire for pilot survey. Pilot survey was conducted among 118 (age group between 23-52 years) respondents across three different states of India namely West Bengal, Andhra Pradesh and Delhi and included businessmen, executives and MBA students of two reputed business schools in India.

These nine items represented the four brand equity dimensions suggested by Aaker (1996a) and were in line with the CBBE scale developed by Yoo and Donthu (2001). The pool had items representing brand awareness (two items), brand image (one item), perceived quality (three items) and brand loyalty (three items). The Cronbach's alpha for the each dimensions were brand awareness (0.80), brand image (0.81), perceived quality (0.79) and brand loyalty $(0.90)$ suggesting that the pool of items is reliable. 


\subsection{Sampling and Main Data Collection}

The basic parameter for selection of the respondent was that the respondent should at least have an under-graduate degree or equivalent level of academic qualification with English as the medium of instruction throughout. This was done to ensure that respondents understand the study questions. This was particularly important for responses from Bangladesh and is in sync with observations made by Sultana (2014) about Bangladeshi students' plight with English as a medium of instruction. For all the questionnaires, seven point bi-polar (strongly disagree strongly agree) Likert type scale was used.

Public diplomacy primarily relates to international audience therefore, the required sample represents international audience. The study has considered Bangladesh as an ideal sample frame for gathering information. In addition, Tyler et al. (2012) and Just (2015) have suggested the importance of domestic public diplomacy, thus the efforts put in by West Bengal administrative machinery to promote the state and its policies among people of West Bengal as well as India was also considered.

In order to collect data from the respondents, this study utilizes web survey method as proposed by Van Gelder and Roeleveld (2010). The data was collected in two stages. The first set of 213 usable responses that represented different occupational backgrounds from India and Bangladesh were explored using exploratory factor analysis (EFA) (refer to Table 4a). To ensure the psychometric objective of our instrument, we carried out second data collection, as using the same set of data can be an issue (Hair et al., 2013). The second sample had similar representations to the first one (refer to Table 4b) and had 437 usable responses and confirmatory factor analysis (CFA) was performed.

Exploratory factor analysis was performed to explore the underlying construct of the items generated which was later subjected to confirmatory factor analysis (Hair et al., 2013). The 
respondents in India were asked about public diplomacy efforts of West Bengal considering what they see, hear and experience from various sources. The Bangladeshi respondents were asked the same thing and other issues they might feel relevant for the ties between Bangladesh and West Bengal, India. Further, the respondents from both nations were asked about place brand equity from the perspective of public diplomacy considering West Bengal as a place brand.

Insert Tables $4 \mathrm{a}$ and $4 \mathrm{~b}$ here.

\subsection{Exploratory Factor Analysis}

The questionnaire to measure CBPBE from the perspective of public diplomacy considering West Bengal as a place brand is used to solicit responses for running exploratory factor analysis. EFA was run on the sample of 213 responses using varimax rotation. The KMO value was 0.76 suggesting that the sample was adequate for the analysis. The EFA analysis suggested a nine items and three factors solution (see Table 5) with $75 \%$ of total variance explained.

Extant literature suggests that total number of factors that results in total variance explained should be greater than 0.6 (Hair et al., 2013). Items with cross loadings or without high factor loadings $(<0.6)$ were omitted from the final factor solution in each of the EFAs. The high factor loadings ( 0.75 to 0.91$)$ suggest that the items provide strong contributions to their respective factors. The Cronbach's alpha for each of the dimensions exhibit reliability with $0.71,0.88$ and 0.86 respectively. The EFA results suggest that the model concurs with the CBBE dimensions of Aaker (1996a, 1996b). The first two items (PD01 and PD02) relates to brand awareness, PD03 is related to brand image, PD04 to PD06 measure perceived quality of the brand. Lastly, PD07 to PD09 measure the level of brand loyalty for the brand. As proposed by Matwiczak (2010), public diplomacy is aimed at 'engagement' with target 
audience. Therefore, we name this as 'Place Brand Engagement'. The nomenclature of 'brand engagement' is purely contextual to this study (as consistent with Matwiczak, 2010) and do not necessarily need to be operationalised from the traditional brand engagement perspective (Sprott, Czellar \& Sprangenberg, 2009; Hollebeek, 2011). Interestingly, unlike Aaker (1996a, 1996b) the present model suggests a structure where brand awareness and brand image have merged to form a single factor. As a result, this dimension can be labeled as 'place brand salience'. Similarly, Romaniuk and Sharp (2004) mention that a salient brand tends to get mentioned (brand awareness/recall) across range of cues (brand association) and images (brand image). Thus association and awareness can be combined (Yoo \& Donthu, 2001).

As argued by Yoo and Donthu (2001), different dimensions of brand equity may be emphasize different marketing strategies, depending on the context, area and cultural focus of the study (p. 12). The three factor model thus closely resembles Yoo and Donthu's (2001) model.

\section{Insert Table 5 here.}

\subsection{Confirmatory Factor Analysis}

The EFA structure is used to run the CFA and subsequent validation tests for the measurement instrument. A new sample of 437 responses were used (refer to Table 6) for the purpose of running the CFA and validation tests. The estimation of the confirmatory model is made using maximum likelihood estimation with Amos 20 (refer to Figure 1).

Results suggest acceptable model fit $\left(\chi^{2} / \mathrm{DF}=3.47, \mathrm{p}=0.01 ; \mathrm{GFI}=0.96\right.$; AGFI $\left.=0.93\right)$. The baseline comparisons $(\mathrm{CFI}=0.97$;FI $=0.96)$ also suggest good model fit (Hair et al., 2013). RMSEA is at 0.07 and is within the acceptable range of 0.05 to 0.08 (Hair et al., 2013). 
Inert Figure 1 here.

\subsection{Convergent and Discriminant Validity}

Table 6 suggests that all the factor loadings are significant and the average variance explained (AVE) for each of the dimensions is greater than the recommended value of 0.5 (Fornell \& Larcker, 1981). The coefficient $\alpha$ for each of the dimensions lies between 0.79 and 0.92 suggesting good internal consistencies. Therefore, the scale fulfills the convergent validity criterion. The squared inter-factor correlation (SIC) (refer to Table 6) values lie between 0.00 and 0.09 and are less than the AVEs. Thus, discriminant validity criterion holds (Fornell \& Larcker, 1981). This suggests that the latent dimensions are unique in measuring CBPBE.

Insert Table 6 here.

\subsection{Nomological Validity}

Nomological validity is tested to examine whether the measures relate to associated constructs in a way that is suggested in literature (Hair et al. 2013). For this purpose two measures of brand loyalty from the CBPBE investment attractiveness scale of Bose et al. (2016) are used and incorporated in the second stage data collection. We earlier have mentioned that public diplomacy is undertaken by regional authorities to woo investors. Boo, Busser and Baloglu, (2009), Bose (2014) and Bose et al., (2016) in their respective studies on model of place brand equity observed that in case of a place brand, loyalty acts as a consequence of brand equity. Therefore, for the validity check we posit that public diplomacy antecedents (place brand salience and perceived quality) will impact the loyalty (brand loyalty

- investment attractiveness) (Bose et al., 2016) towards the place among investors. We use 
brand engagement as a mediator between the above mentioned constructs and posit that brand salience and perceived quality impact brand loyalty - investment attractiveness through brand engagement. We thereby hypothesize that:

H1: Place brand salience and perceived quality significantly effect brand engagement

H2: Place brand engagement significantly effects brand loyalty (investmment attractiveness).

The model (refer to Figure 2) is tested and the results discussed.

Insert Figure 2 here.

Results of the model suggests good model fit $\left(\chi^{2} / \mathrm{DF}=3.33, \mathrm{p}=0.01 ; \mathrm{GFI}=0.95 ;\right.$ AGFI $\left.=0.92\right)$. The baseline comparisons $(\mathrm{CFI}=0.97$;FI $=0.95)$ also suggest good model fit (Hair et al. 2013). RMSEA is at 0.07 and is within the acceptable range of 0.05 to 0.08 (Hair et al., 2013). Moreover, all the relations between the constructs were positive and significant at $p<0.01$. In the nomological model the impact of place brand salience on place brand engagement was significant $(\beta=0.17, \mathrm{t}=3.12, \mathrm{p}<.01)$; impact of perceived quality on place brand engagement was significant $(\beta=0.22, \mathrm{t}=4.23, \mathrm{p}<.01)$; and impact of place brand engagement on brand loyalty was significant $(\beta=0.26, \mathrm{t}=.72, \mathrm{p}<.01)$ was significant. Thus, hypotheses H1and H2 were supported. This corroborates the opinions of place branding scholars (Anholt, 2005; Jacobsen 2009; Bose, 2014) that loyalty towards a place could result in loyalty towards the same place in the context of interest in investments.

The results indicate that the dimensions of place brand equity hold positive relationship with other constructs of CBPBE (investment attractiveness perspective) thus supporting extant CBBE literature (Aaker, 1996a; Keller, 1993; Pitta \& Kutsanis, 1995). Therefore, it can be concluded that the nomological validity criterion is met by the instrument. 


\section{Discussion and Overall Assessment}

The aim of this study was to develop a quantifiable measure of customer based place brand equity given the dearth of such quantitative measures of the construct (Bose, 2014; Bose et al., 2016). In this regard, place brand equity gained some prominence given the special issue in Place Branding and Public Diplomacy in 2015. However, Giovanardi and Lucarelli (2018) point out that quantifiable measurement of brand equity of a place has primarily been restricted to the studies by Florek (2015) and Bose et al (2016). We approached CBPBE from the perspective of public diplomacy given the abject deficiency of work that bridged the gap between two seemingly unrelated domains of branding (marketing) and public diplomacy (Anholt, 2005). For the study, the east Indian state of West Bengal was chosen as the place brand and Bangladesh the audience (customers) to its public diplomacy efforts. The historical and socio-political relations between the two places made West Bengal an interesting context.

Through exploratory study, a nine item measure of CBPBE from the perspective of public diplomacy was initially proposed. Interestingly, during the EFA, item considering the place to be 'affable and visitor friendly' (PD03) merged with two other items (PD01 and PD02) that measure awareness about public diplomacy efforts made by a particular place to form a single factor. Although PD03 was suggested to represent a single and independent measure of brand image as in the previous literatures (Hafeez et al., 2016), the respondents of the current study might have considered this item as an extension of the awareness dimension and responded likewise. The CFA with 437 respondents suggests good fit and robustness of the instrument. AVEs ranging between 0.56 and 0.78 along with coefficient $\alpha$ between 0.79 and 0.92 ensure convergent validity. The AVEs were considerably higher than the SICs suggesting discriminant validity for the instrument.

Moreover, the tests for nomological validity suggests that brand salience and perceived quality dimensions impact the brand engagement of a place as well as brand loyalty from the 
point of view of investment. This supports the opinions of Aaker (1996a), Keller (1993 and Pitta and Kutsanis, (1995) pertaining to CBBE paradigm. Moreover, it also supports observations made by Bose (2014) and Bose et al. (2016) that perspectives of place brand equity investment attractiveness and public diplomacy can be inter-related. Therefore, it can deduced that the CBPBE instrument considering public diplomacy is robust and is representative of existing CBBE measures in the context of a 'place' and from the perspective of public diplomacy efforts undertaken by that 'place' brand.

\section{Contributions, Implications and Recommendations}

The study addresses place branding and subsequently, place brand equity from the perspective of public diplomacy for a particular place brand, namely West Bengal. The study develops an instrument called the CBPBE. Results indicate a three dimensional structure of the CBPBE scale that represents brand awareness/brand image, perceived quality, and brand loyalty. The instrument has stable psychometric properties and is similar to the conceptualization of Aaker's (1996a) CBBE dimensions. This study has significant theoretical contributions as well as managerial implications given the limitations of the study. We also suggest future research directions.

\subsection{Contributions}

Theoretically, the study contributes to place branding, brand equity, public diplomacy, international relations, and public relations literature. Firstly, it shows that a place can be considered much like a brand as any of the products or services and thus can be subjected to brand equity analysis. Secondly, it bridges the gap between place branding literature and international relations and/or public diplomacy by offering a fresh insight using three different methods into how a place brand can achieve its brand equity through public diplomacy, via marketing and branding orientation. Although both concepts (place branding and public 
diplomacy) are two important concepts, which are highly connected and can be bridged (Gilboa, 2008; Anholt, 2010), the empirical evidence however were scarce since they were explored separately within the two disciplines. Furthermore, most available works were either historical, anecdotal or personal views, lack of theoretical background and majority use qualitative method, thus, empirical validation and relationship are still unclear. Yet, the importance of bridging these two concepts and explaining how they work from the marketing perspective are vital because they can both potentially solve tensions between two states in the case of dispute and/ or foster friendly relations between them. Therefore, through public diplomacy campaign may increase publics understanding of an issue which potentially enhances the place brand's image (Bose et al., 2016). We therefore offer a new way of how public diplomacy can be used within a place brand's marketing strategy. In particular, the scale development effort addresses this ideological gap by identifying items that can measure brand equity of a place from the perspective of how recognizable it is as to the target audience given the public diplomacy efforts of the administration. It also measures the sets of positive or negative images a place holds in the minds of the targeted audience (brand salience), the perceived credibility, believability and quality of the information provided by the administration (perceived quality) and how much interests towards the place and its promotional activities have actually been generated among the target audience as they were exposed to the public diplomacy efforts (brand engagement). This in turn can lead to further study by public diplomacy practitioners, scholars and place marketers to examine the differences in overall brand equity and/or individual dimensions of place brand equity among prospective/first time audience and those who are already exposed to the public diplomacy efforts made by the 'place' brand.

\subsection{Place Brand Equity and the Public Diplomacy Team}


As from the practitioner's point view, the public diplomacy team can utilize this instrument as a basis for quantitatively measure the effect of their public diplomacy programs among the target audience. Moreover, this instrument can be used with the overall brand equity measure (Yoo \& Donthu, 2001) to understand to what extent the public diplomacy efforts have affected the overall brand perception about the place among the target audience.

\subsection{Place Brand Equity and the Place Marketer}

While marketing a place to the global audience, place marketers need to work in tandem with the public diplomacy efforts. Moreover, the impact of public diplomacy efforts can be seen on the approaches to place marketing strategies. The instrument developed in this study will aid place marketers to understand the impact of the place's public diplomacy efforts on the target audience and subsequently, could strategise their marketing activities for the 'place' so as to maximize the brand leveraging opportunities borne out of public diplomacy.

\subsection{Brand Communication Practitioner and Public Diplomacy as a Practice}

In addition, this study opens up great opportunities for brand communication practitioners to use their expertise in promoting a place among its target audiences and create positive opinions about the same. Thus, it enables to bridge the practitioner related gap between the two professions. Moreover, brand communication practitioners engaged in promoting places and destinations can work in tandem with the public diplomacy team to create a public diplomacy program that is built around the place brand itself like that of ' $100 \%$ Pure New Zealand' branding strategy (Morgan, Pritchard \& Piggott, 2002).

\subsection{Limitations and Directions for Future Research}


Public diplomacy has traditionally been researched by scholars of international relations and political science. Branding on the other hand is a traditional marketing domain. Therefore, adopting these two diverse approaches for a common cause in it has challenges. The lack of quantitative measurement approaches towards public diplomacy led the researchers to go for exploratory studies to generate such measures. Some level of subjectivity and personal bias into development of these items is apprehended. We also acknowledge that only 11 items could be generated of which only nine items remain in the final scale.

These limitations leave opportunities for future research pertaining to improvement and purificationon of this scale by exploring new measures of CBPBE. Due to the lack of any comprehensive model, the researchers made Aaker's (1996a) and Keller's (1993) CBBE dimensions as base to develop the new measurement instrument. Alternative approach to this process might result in different measures and can be explored.

The sample represents nationals from just two nations due to paucity of resources. The state of West Bengal, also shares borders with the countries of Bhutan and Nepal. Therefore, incase of a need to 'adopt' the scale responses from those nations may have provided richer outcomes.

Context specificity of places cannot be accommodated by the traditional branding theory (Warnaby, 2009). Therefore, there is an opportunity to 'adapt' and apply this scale in different international place (including country) specific contexts. This in turn may lead to development of new measures of place brand equity from the public diplomacy perspective which may enhance the richness and the robustness of the present instrument.

We believe that the scale can act as a base for further improvement of the CBPBE and CBBE measures by future researchers. The present scale can further enhance such models by examining the inter-plays of the other brand equity perspectives namely, destination branding, regional identity and investment attractiveness. Our nomological validity test was one such 
simple inter-disciplinary model. The proposed instrument should thus motivate further research that provides meaningful and helpful insights to public diplomacy efforts and its CBPBE antecedents and consequences thereof. One such interesting research area could be to see the interplay of regional identity and/ or destination branding with public diplomacy given West Bengal's geographic location. This study can lead to newer insights when investment attractiveness is put into the model as a consequence of West Bengal's place brand equity given its geography. 


\section{References}

Aaker, D. A. (1996a). Building Strong Brands. New York: Free Press

Aaker, D. A. (1996b). Measuring Brand Equity across Products and Markets. California Management Review, 38 (3), 102-120.

Anholt, S. (2005).Some Important Distinctions in Place Branding. Place Branding and Public Diplomacy, 1(2), 116-121.

Anholt, S. (2007). Competitive Identity, UK: Palgrave Macmillan..

Anholt, S. (2010). Definitions of Place Branding - Working towards a Resolution. Place Branding and Public Diplomacy, 6 (1), 1-10.

Askegaard, S. \& Kjeldgaard, D. (2007). Here, There and Everywhere: Place Branding and Gastronomical Globalization in a Macromarketing Perspective. Journal of Macromarketing, 27(2), 138-147.

Baines, P. R., O'Shaughnessy, N. J., Maloney, K., Richards, B., Butler, S., \& Gill, M. (2010). The Dark Side of Political Marketing: Islamist Propaganda, Reversal Theory and British Muslims. European Journal of Marketing, 44 (3/4), 478-495.

Banks, R. (2011). A Resource Guide to Public Diplomacy Evaluation. CPD Perspectives on Public Diplomacy, Working Paper No. 9, USC Center on Public Diplomacy, Annenberg School.

Basu, P. P. (2007). Brand Buddha in India’s West Bengal: The Left Reinvents itself. Asian Survey, 47 (2), 288-306.

Bhardwaj, S. K. (2011). Contesting Identities in Bangladesh: A Study of Secular and Religious Frontiers. Asia Research Centre, Working Papers No. 36, London School of Economics.

Bloom Consulting (2016). Bloom Consulting Country Brand Index (accessed on November 7 , 2017) [available at http://www.bloom-consulting.com/en/country-brand-ranking].

Bond, R., McCrone, D., \& Brown, A. (2003). National Identity and Economic Development: Reiteration, Recapture, Reinterpretation and Reputation. Nations and Nationalism, 9 (3), 371-391.

Boo, S., Busser, J., \& Baloglu, S. (2009). A model of customer- based brand equity and its application to multiple destinations. Journal of Business Research, 30(2), 219-231.

Bose, S. (2014). Branding “West Bengal” antecedents and consequences of place branding strategies with respect to destination branding public diplomacy and regional identity. Doctoral dissertation, ICFAI University, Dehradun, India. 
Bose, S., Roy, S. K. \& Nguyen, B. (2016). Developing a Conceptual Framework for Place Image. In Asia Branding, TC Melewar, Bang Nguyen and Don E. Schultz, eds. pp. 150173, Palgrave, United Kingdom, Palgrave.

Caldwell, N. \& Frier, J. R. (2004). The Differences between Branding a Country, A Region and A City: Applying the Brand Box Model. Journal of Brand Management, 12 (1), 50-61.

Cardinale, S., Nguyen, B., \& Melewar, T.C. (2016). Place-Based Brand Experience, Place Attachment and Loyalty. Marketing Intelligence and Planning, 34 (3), 302-317.

Daily World (2017). Bangladeshi Tourists avoiding Darjeeling: Officials. (accessed 21 July, 2017), [available at https://dailyworld.in/bangladeshi-tourists-avoiding-darjeeling-officials/].

Dash, D. K. (2016). India Keen to Develop Strategically Important Deep Sea Port in Bangladesh. (accessed 6 March, 2017), [available at www.timesofindia.indiatimes.com].

Dayal, R. (2012). India's Eastern Promises. (accessed 21 November, 2013), [available at www.thehindu.com]. .

Dinnie, K. (2004). Place Branding: An Overview of an Emerging Literature. Place Branding and Public Diplomacy, 1 (1), 106-110.

Dinnie, K. (2005). Brand America: The Mother of all Brands. Journal of Brand Management, 12 (5), 405-406.

Dinnie, K. (2008). Nation Branding: Concepts, Issues, Practice, UK: Oxford.

Dutta, P. (2004). Push-Pull Factors of Undocumented Migration from Bangladesh to West Bengal: A Perception Study. The Qualitative Report, 9 (2), 335-358.

Donner, M., Fort, F., \& Vellema, S. (2014). How to capture place brand equity? The case of Sud de France. Place Branding and Public Diplomacy, 10(2), 145-157.

Elliot, S., Popadopoulos, N., \& Kim, S. S. (2010). An Interactive Model of Place Image: Exploring Relationship between Destination, Product and Country Images. Journal of Travel Research, 20 (10), 1-15.

Fan, Y. (2010). Branding the Nation: Towards a Better Understanding. Place Branding and Public Diplomacy, 6 (2), 97-103.

Fern, E. F. (1983). Focus Groups: A Review of Some Contradictory Evidence, Implications, and Suggestions for Future Research. Advances in Consumer Research, 10 (1), 121-126.

Fetscherin, M. \& Toncar, M. (2010). The Effects of Country Brand and Country of Manufacturing of Automobiles: An Experimental Study of Consumer's Brand Personality Perceptions. International Marketing Review, 27 (2), 164-178. 
Florek, M. (2015). Rethinking brand equity_possibilities and challenges of application to places. In Rethinking Place Branding (pp. 225-239). Springer International Publishing.

Fornell, C. \& Larcker, D. F. (1981). Evaluating structural equation models with unobservable variables and measurement error. Journal of Marketing Research, 18 (1), 39-50.

Foroudi, P., Gupta, S., Kitchen, P., Foroudi, M.M., \& Nguyen, B. (2016). A Framework of Place Branding, Place Image, and Place Reputation: Antecedents and Moderators. Qualitative Market Research: An International Journal, 19 (2), 241-264.

Frederick, H.H. (1993). Global Communication and International Relations. California: Thomson Publishers Inc.

FutureBrand (2016). Country Brand Index. (accessed November 7, 2017), [available at https://www.futurebrand.com/country-brand-index].

García, J. A., Gómez, M., \& Molina, A. (2012). A destination-branding model: An empirical analysis based on stakeholders. Tourism Management, 33(3), 646-661.

Gartner, W. C. \& Maja, K. (2010). Tourism Brand Equity Dimensions: Renewal versus Repeat Market. Journal of Travel Research, 20 (10), 1-11.

Gertner, D. (2011). Unfolding and configuring two decades of research and publications on place marketing and place branding. Place Branding and Public Diplomacy, 7(2), 91-106.

GfK (2016). Anholt-GfK Roper Nations Brand Index. (accessed November 7, 2017), [available at http://nation-brands.gfk.com/].

Gilboa, E. (2008). Searching for a theory of public diplomacy. The Annals of the American Academy of Political and Social Science, 616(1), 55-77.

Giovanardi, M. \& Lucarelli, A. (2018). Sailing through marketing: A critical assessment of spatiality in marketing literature. Journal of Business Research, 82, 149-159.

Hafeez, K., Faroudi, P., Dinnie, K., Nguyen, B., \& Parahoo, S.K. (2016). The Role of Place Branding and Image in the Development of Sectoral Clusters: The Case of Dubai. Journal of Brand Management, 23 (4), 383-402.

Hair Jr., Joseph F., William C. Black, Barry J. Babin, \& Rolph, E. Anderson (2013). Multivariate Data Analysis, NJ: Prentice Hall.

Ham, P. V. (2001). The Rise of the Brand State: The Postmodern Politics of Image and Reputation. Foreign Affairs, 80 (5), 2-6.

Ham, P. V. (2002). Branding Territory: Inside the Wonderful Worlds of PR and IR Theory. Millennium, 31 (2), 246-269. 
Hildrith, J. (2008). The European City Brand Barometer-Revealing which cities get the brands they deserve. London: Saffron Brand Consultants.

Hinkin, T. R. (1998). A Brief Tutorial on the Development of Measures for Use in Survey Questionnaires. Organizational Research Methods, 1(1), 104-121.

Hollebeek, L. (2011). Exploring customer brand engagement: definition and themes. Journal of Strategic Marketing, 19(7), 555-573.

Im, H. H., Kim, S. S., Elliot, S., \& Han, H. (2012). Conceptualizing destination brand equity dimensions from a consumer-based brand equity perspective. Journal of Travel \& Tourism Marketing, 29(4), 385-403.

Jacobsen, B. P. (2009). Investor- based place brand equity: A theoretical framework. Journal of Place Management and Development, 2(1), 70-84.

Jones, D. \& Smith, M.L.R. (2006). The Commentariat and Disclosure Failure: Language and Atrocity in Cool Britannia. International Affairs, 6 (6), 1077-1100.

Just, T. (2015). Public diplomacy and domestic engagement: The Jewish revival in Poland. Place Branding and Public Diplomacy, 11(4), 263-275.

Kavaratzis, M. \& Ashworth, G (2008). How Did We Get Here and Where are We Going? Journal of Place Management and Development, 1 (2), 150-165.

Keller, K. L. (1993). Conceptualizing, Measuring and Managing Customer Based Brand Equity. Journal of Marketing, 57 (1), 1-22.

Kendrik, A. \& Fullerton, J. A. (2004). Advertising as Public Diplomacy: Attitude Change Among International Audiences. Journal of Advertising Research, 44 (3), 297-311.

Kladou, S. \& Kehagias. J. (2014). Assessing destination brand equity: An integrated approach. Journal of Destination Marketing \& Management, 3 (1), 2-10.

Kotler, P. \& David, G. (2002). Country as Brand, Product, and Beyond: A Place Marketing and Brand Management Perspective. Journal of Brand Management, 9 (4/5), 249-261.

Leight, N. (2013). Cases on Water Diplomacy. CPD Perspectives on Public Diplomacy, Working Paper No. 2, USC Center on Public Diplomacy, Annenberg School.

Malone, G. D. (1985). Managing Public Diplomacy. Washington Quarterly, 8 (3), 199-210. Matwiczak, K. (2010). Public Diplomacy: Model for the Assessment of Performance. Public Research Project Report No. 170, Lyndon B. Johnson School of Public Affairs.

Melissen, J. (2005). The New Public Diplomacy: Between Theory and Practice. In The New Public Diplomacy, J. Melissen, ed. Palgrave, New York: Macmillan, 3-27. 
Merrilees, B., Miller, D. \& Herington, C. (2012). Multiple stakeholders and multiple city brand meanings. European Journal of Marketing, 46(7/8), 1032-1047.

Merrilees, B., Miller, D., \& Herington, C. (2013). City branding: A facilitating framework for stressed satellite cities. Journal of Business Research, 66(1), 37-44.

Morgan, N., Pritchard, A., \& Piggott, R. (2002). New Zealand, 100\% pure. The creation of a powerful niche destination brand. Journal of Brand Management, 9(4), 335-354.

Netemeyer, Richard G., Balaji Krishnan, Chris Pullig, Guangping Wang, Mehmet Yagci, Dwane Dean, Joe Ricks, \& Ferdinand, W (2004). Developing and Validating Measures of Facets of Customer-Based Brand Equity. Journal of Business Research, 57 (2), 209-224.

Olins, W. (2005). Making a National Brand. In The New Public Diplomacy, J. Melissen, ed. Palgrave, New York: Macmillan, 169-79.

Oliver, R. L. (1999). Whence Consumer Loyalty? Journal of Marketing, 63, 33-44.

Pahlavi, P. C. (2007). Evaluating Public Diplomacy Programs. The Hague Journal of Diplomacy, 2 (3), 255-281.

Paliaga, M., Zoran, F. \& Zelijko, S. (2010). Methodology of valuation of cities' brands. Economic Research-Ekonomska Istraživanja, 23(2), 102-111.

Pamment, J. (2014). Articulating influence: Toward a research agenda for interpreting the evaluation of soft power, public diplomacy and nation brands. Public Relations Review, 40(1), 50-59.

Papadopoulos, N. \& Heslop, L. (1993). Product-Country Images: Impact and Role in International Marketing, London: Routledge.

Papadopoulos, N. \& Heslop, L. (2002). Country Equity and Country Branding: Problems and Prospects. Journal of Brand Management, 9 (4/5), 294-314.

Pappu, R., Quester, P. \& Cooksey, R. W. (2007). Country Image and Consumer-Based Brand Equit. Journal of International Business Studies, 38 (5), 726-745.

Pike, S. D. (2007). Consumer Based Brand Equity for Destinations: Practical DMO Performance, L.e Measures. Journal of Travel and Tourism Marketing, 22 (1), 51-61.

Pike, S. D. (2009). Destination Brand Positions of a Competitive Set of Near-Home Destinations. Tourism Management, 30 (6), 857-866.

Pitta, D. A. \& Katsanis, L. P. (1995). Understanding Brand Equity for Successful Brand Extension. Journal of Consumer Marketing, 12 (4), 51-64. 
Prendergast, G. P., Tsang, A. S. L. \& Chan, C. N. W. (2010). The Interactive Influence of Country of Origin of Brand and Product Involvement on Purchase Decision. Journal of Consumer Marketing, 27 (2), 180-188.

Rainisto, S. K. (2003). Success Factors of Place Marketing: A Study of Place Marketing Practices in Northern Europe and The United States. Doctoral dissertation, Helsinki University of Technology, Finland.

Romaniuk, J. \& Sharp, B. (2004). Conceptualizing and Measuring Brand Salience. Marketing Theory, 4(4), 327-342.

Ruzzier, M. K., \& De Chernatony, L. (2013). Developing and applying a place brand identity model: The case of Slovenia. Journal of Business Research, 66(1), 45-52.

Sevin, H. E. (2014). Understanding cities through city brands: City branding as a social and semantic network. Cities, 38, 47-56.

Sevin, H. E. (2015). Pathways of connection: An analytical approach to the impacts of public diplomacy. Public Relations Review, 41(4), 562-568.

Shafranskaya, I., \& Potapov, D. (2014). An empirical study of consumer-based city brand equity from signalling theory perspective. Place Branding and Public Diplomacy, 10(2), 117-131.

Shamshad, R. (2017). Bengaliness, Hindu nationalism and Bangladeshi migrants in West Bengal, India. Asian Ethnicity, 18(4), 433-451.

Signitzer, B. H. \& Coombs, T. (1992). Public Relations and Public Diplomacy: Conceptual Divergence. Public Relations Review, 18 (2), 137-147.

Singleton, H. \& McKenzie, F. H. (2008). The Re-Branding Imperative for the Western Australian Pilbara Region: Status Quo to Transformative Cultural Interpretations of Local Housing and Settlement for a Competitive Geo-Regional Identity. Place Branding and Public Diplomacy, 4 (1), 8-28.

Smith, A. D. (1991). National Identity, London: Penguin Books.

Sprott, D., Czellar, S., \& Spangenberg, E. (2009). The importance of a general measure of brand engagement on market behavior: Development and validation of a scale. Journal of Marketing Research, 46(1), 92-104.

Sultana, S. (2014). English as a Medium of Instruction in Bangladesh's Higher Education: Empowering or Disadvantaging Students? Asian EFL Journal, 16(1), 11-52.

Szondi, G. (2008). Public Diplomacy and Nation Branding: Conceptual Similarities and Differences. Discussion Papers in Diplomacy, Netherlands Institute of International Relations Clingendael. 
Tewari, F. \& Pant, H. V. (2016). Paradiplomacy and India: Growing Role of States in Foreign Policy. (accessed on March 6, 2017), [available at www.orfonline.org].

Tuch, H. N. (1990). Communicating with the World: US Diplomacy Overseas. New York: Macmillan.

Turner, D. W. (2010). Qualitative Interview Design: A Practical Guide for Novice Investigators. The Qualitative Report, 15(3), 754-760.

Tyler, M. C., Abbasov, A., Gibson, N. \& Teo, F. (2012). Domestic Public Diplomacy. Discussion paper series, Australian Institute of International Affairs, Deakin, AIIA.

Wang, J. (2006). Localising Public Diplomacy: The Role of Sub-National Actors in Nation Branding. Place Branding, 2 (1), 32-42.

Warnaby, G. (2009). Towards a Service-Dominant Place Marketing Logic. Marketing Theory, $9(4), 403-423$.

Williams, D. R., McDonald, C. D., Riden, C. M. \& Uysal, M. (1995). Community Attachment, Regional Identity and Resident Attitudes towards Tourism. Proceedings of the $26^{\text {th }}$ Annual Travel and Tourism Research Association Conference Proceedings, 424-428.

Van Gelder, M. M., Bretveld, R. W. \& Roeleveld, N. (2010). Web-based questionnaires: the future in epidemiology? American Journal of Epidemiology, 172(11), 1292-1298.

Vibrant Gujarat Summit (2012). (accessed December 30, 2012), [available at www.vibrantgujarat.com].

Yan, J. (2003). Nation Branding: Branding and the International Community. Journal of Brand Management, 10 (6), 447-456.

Yoo, B. \& Donthu, N. (2001). Developing and Validating a Multidimensional Consumer-Based Brand Equity Scale. Journal of Business Research, 52 (1), 1-14.

Zenker, S. \& Braun, N. (2010). Branding City: A Conceptual Approach for Place Branding and Place Brand Management. Proceedings of $39^{\text {th }}$ European Marketing Academy Conference, Copenhagen.

Zenker, S. \& Martin, N. (2011). Measuring Success in Place Marketing and Branding. Place Branding and Public Diplomacy, 7(1), 32-41.

Zenker, S. (2014). Measuring Place Brand Equity with the Advanced Brand Concept Map (aBCM) Method. Place Branding and Public Diplomacy, 10(2), 158-166. 
Table 1. Sources of CBPBE Items

\begin{tabular}{|l|l|}
\hline Source & Item \\
\hline Pahlavi (2007) & Broadcasting programs (Media and promotion) \\
\cline { 2 - 2 } & Cultural programs (Exhibitions, exchanges) \\
\cline { 2 - 2 } & Level of awareness of diplomacy programs \\
\cline { 2 - 2 } & Measurement of foreign opinion \\
\hline Matwiczak (2010) & Change in opinion of local communities \\
\cline { 2 - 2 } & Satisfaction scores of public diplomacy programs \\
\cline { 2 - 2 } & Improved / increased understanding about the concerned region \\
\cline { 2 - 2 } & Loyalty towards the concerned region (reduction in antipathy) \\
\hline Banks (2011) & Information credibility \\
\cline { 2 - 2 } & Proof of earnestness of the concerned region to reach out \\
\hline
\end{tabular}

Table 2. Thematic Analyses of Place brand Equity

\begin{tabular}{|c|c|c|}
\hline Content & Theme & Attribute \\
\hline \multirow[t]{9}{*}{ Public diplomacy } & \multirow[t]{4}{*}{ State machinery } & Government's image \\
\hline & & Image of responsibility \\
\hline & & Government performance \\
\hline & & Political environment of the state \\
\hline & \multirow{2}{*}{$\begin{array}{l}\text { Political } \\
\text { Relations }\end{array}$} & Relation and interaction with the centre \\
\hline & & $\begin{array}{l}\text { Diplomatic issues with neighbour regions and } \\
\text { countries }\end{array}$ \\
\hline & \multirow[t]{3}{*}{ Propaganda } & $\begin{array}{l}\text { Relationship with different sectors of the region } \\
\square \text { Industrial } \\
\square \text { Educational } \\
\square \text { Ethnic } \\
\square \text { Agricultural } \\
\square \text { Social }\end{array}$ \\
\hline & & Policy decisions \\
\hline & & Media relations \\
\hline
\end{tabular}


Table 3. Emergent themes in the depth interviews

\begin{tabular}{|c|c|}
\hline Theme & Attribute \\
\hline \multirow[t]{4}{*}{ Propaganda } & Image of the government \\
\hline & Political environment \\
\hline & Image created by media \\
\hline & $\begin{array}{l}\text { Actions of the government } \\
\square \text { Political climate } \\
\square \text { Relation with industry } \\
\square \text { Responsibility shown towards incidents and crises } \\
\square \text { Policy decisions }\end{array}$ \\
\hline \multirow[t]{2}{*}{ History } & Image of the region in recent history \\
\hline & Political events and movements \\
\hline \multirow[t]{2}{*}{$\begin{array}{l}\text { Actions and } \\
\text { consequences }\end{array}$} & $\begin{array}{l}\text { Consequences of actions taken by the regional authorities } \\
\square \text { Domestic audience } \\
\square \text { International audience } \\
\square \text { Audience in the effected country and/or region }\end{array}$ \\
\hline & $\begin{array}{l}\text { Relations with national and international (regional) governments } \\
\text { and/or authorities }\end{array}$ \\
\hline
\end{tabular}

Table 4a. Sample for measuring CBPBE from the perspective of public diplomacy (EFA)

\begin{tabular}{|c|c|c|c|c|}
\hline \multicolumn{5}{|c|}{ Number of respondents based on nationality } \\
\hline \multicolumn{3}{|c|}{ India } & \multicolumn{3}{c|}{ Bangladesh } \\
\hline \multicolumn{4}{|c|}{122} & \multicolumn{3}{c|}{91} \\
\hline \multicolumn{5}{|c|}{ Number of respondents based on occupation } \\
\hline Service & Business & Professional & Student & Others \\
\hline 85 & 70 & 40 & 13 & 5 \\
\hline
\end{tabular}

Table 4b. Sample for measuring CBPBE from the perspective of public diplomacy (CFA)

\begin{tabular}{|c|c|c|c|c|}
\hline \multicolumn{5}{|c|}{ Number of respondents based on nationality } \\
\hline \multirow{2}{*}{\multicolumn{2}{|c|}{ India }} & & \multicolumn{2}{|c|}{ Bangladesh } \\
\hline & & & & \\
\hline \multicolumn{5}{|c|}{ Number of respondents based on occupation } \\
\hline Service & Business & Professional & Student & Others \\
\hline 153 & 139 & 84 & 36 & 25 \\
\hline
\end{tabular}


Table 5. Exploratory factor analysis for CBPBE from the perspective of public diplomacy

\begin{tabular}{|c|c|c|c|}
\hline Dimension & Measurement Items & Code & $\begin{array}{l}\text { Factor } \\
\text { Loadings } \\
\end{array}$ \\
\hline \multirow{3}{*}{$\begin{array}{l}\text { Place Brand } \\
\text { Salience }\end{array}$} & The place (as a part of a country) is well known & PD01 & 0.839 \\
\hline & $\begin{array}{l}\text { I come to know about the place through different } \\
\text { activities undertaken by concerned authorities }\end{array}$ & PD02 & 0.775 \\
\hline & The place is affable and visitor friendly & PD03 & 0.745 \\
\hline \multirow{3}{*}{$\begin{array}{l}\text { Perceived } \\
\text { Quality }\end{array}$} & $\begin{array}{l}\text { The authorities send across credible information about } \\
\text { the place }\end{array}$ & PD04 & 0.876 \\
\hline & $\begin{array}{l}\text { The expos, road shows, discussion forums, conventions } \\
\text { etc. organized by the authorities to provide information } \\
\text { about the place are entertaining }\end{array}$ & PD05 & 0.886 \\
\hline & $\begin{array}{l}\text { The expos, road shows, discussion forums, conventions } \\
\text { etc. organized by the authorities to provide information } \\
\text { about the place are informative }\end{array}$ & PD06 & 0.861 \\
\hline \multirow{3}{*}{$\begin{array}{l}\text { Place Brand } \\
\text { Engagement }\end{array}$} & $\begin{array}{l}\text { I am interested in taking part in various promotional } \\
\text { activities and functions organized or performed by the } \\
\text { authorities of that concerned place }\end{array}$ & PD07 & 0.830 \\
\hline & $\begin{array}{l}\text { I would like to avail the opportunity to participate in } \\
\text { promotional activities organized the authorities of the } \\
\text { concerned place }\end{array}$ & PD08 & 0.908 \\
\hline & $\begin{array}{l}\text { I would suggest others to participate in the place's } \\
\text { promotional activities }\end{array}$ & PD09 & 0.835 \\
\hline
\end{tabular}


Table 6. CFA loadings, scale reliability and validity (CFA) - CBPBE from the perspective of public diplomacy

\begin{tabular}{|c|c|c|c|c|c|c|}
\hline & \multirow[b]{2}{*}{$\begin{array}{l}\text { CFA } \\
\text { loadings }\end{array}$} & \multirow{2}{*}{$\begin{array}{l}\text { Composite } \\
\text { Reliability }\end{array}$} & \multirow[b]{2}{*}{ AVE } & \multicolumn{3}{|c|}{ Squared Inter-group Correlations } \\
\hline & & & & $\begin{array}{l}\text { Place Brand } \\
\text { Salience }\end{array}$ & $\begin{array}{l}\text { Perceived } \\
\text { Quality }\end{array}$ & $\begin{array}{l}\text { Place Brand } \\
\text { Engagement }\end{array}$ \\
\hline & & & & 1 & 0.087 & 0.044 \\
\hline $\begin{array}{l}\text { Place Brand } \\
\text { Salience } \\
\text { PD01 } \\
\text { PD02 } \\
\text { PD03 }\end{array}$ & $\begin{array}{l}.816 \\
.77 \\
.56\end{array}$ & .77 & .53 & & & \\
\hline $\begin{array}{l}\text { Perceived } \\
\text { Quality } \\
\text { PD04 } \\
\text { PD05 } \\
\text { PD06 }\end{array}$ & $\begin{array}{l}.78 \\
.95 \\
.86\end{array}$ & .90 & .75 & --- & 1 & 0.051 \\
\hline $\begin{array}{l}\text { Place Brand } \\
\text { Engagement } \\
\text { PD07 } \\
\text { PD08 } \\
\text { PD09 }\end{array}$ & $\begin{array}{l}.912 \\
.864 \\
.887\end{array}$ & .92 & .79 & --- & --- & 1 \\
\hline
\end{tabular}


Figure 1: Measurement model

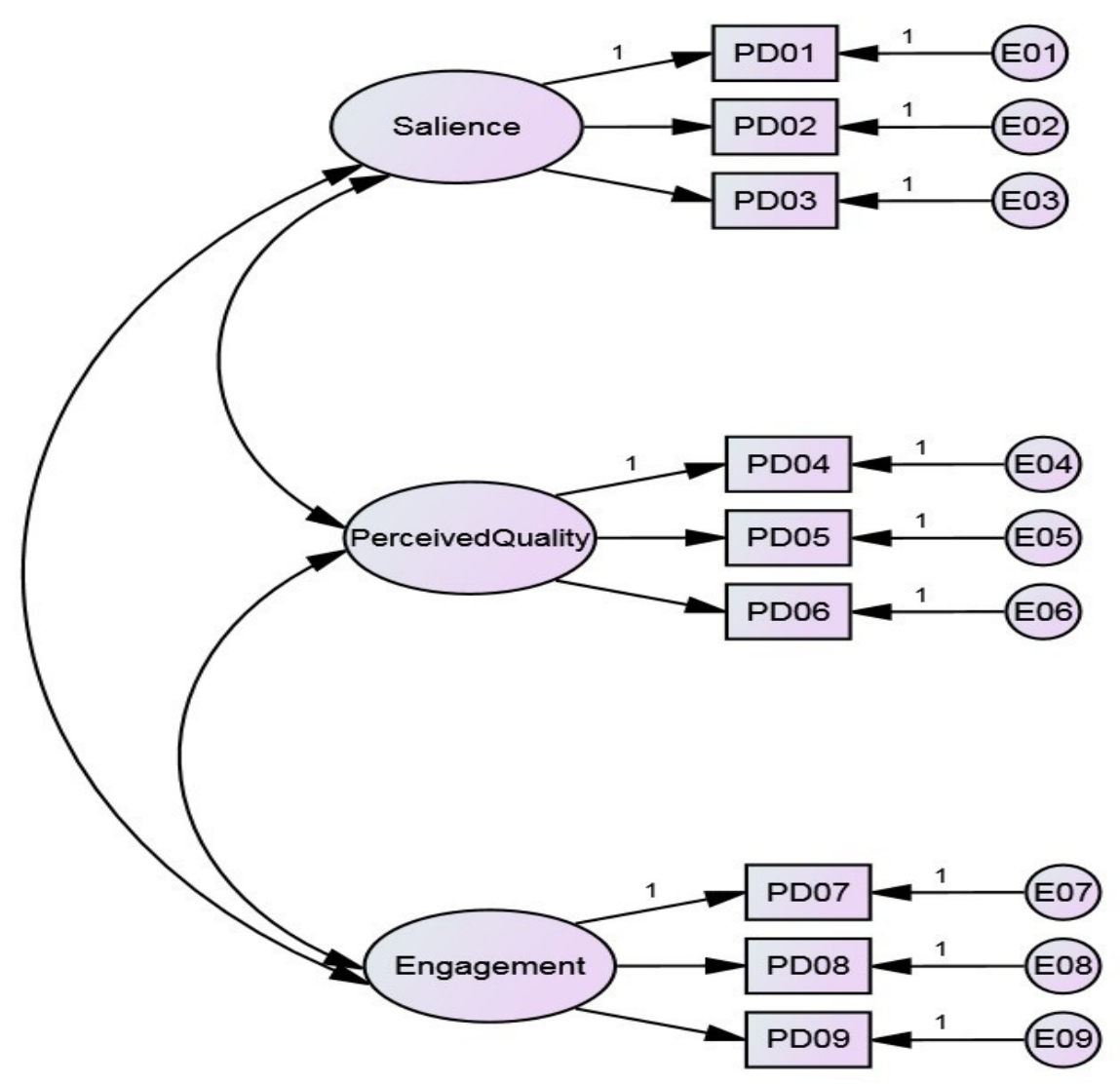


Figure 2. Nomological validity model for CBPBE

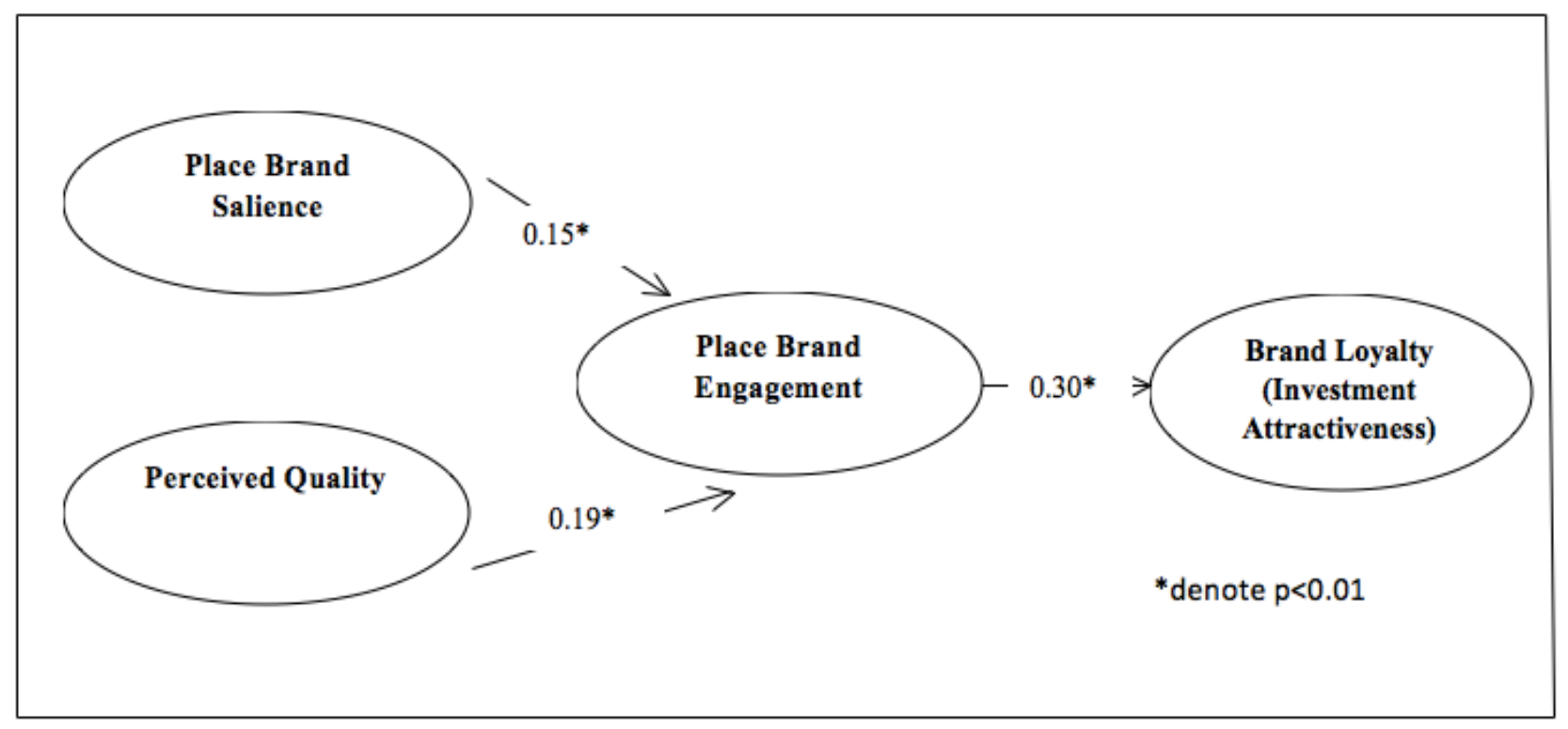

